tive symbols for Internal Energy, Entropy and Heat Content respectively.

(3) That thermodynamic quantities should always be expressed in the Centigrade scale of temperature.

TABLE II. SYMBOLS FOR THERMODYNAMIIO QUANTITIES

\begin{tabular}{|c|c|c|c|c|c|c|}
\hline Name & Entropy & $\begin{array}{c}\text { Internal } \\
\text { Energy }\end{array}$ & $\begin{array}{c}\text { Free } \\
\text { Energy }\end{array}$ & $\begin{array}{c}\text { Thermal Poten- } \\
\text { tial or Gibbs } \\
\text { Function }\end{array}$ & $\begin{array}{c}\text { Heat Con- } \\
\text { tent or } \\
\text { Enthalpy }\end{array}$ & Work \\
\hline Formula & - & - & $U-T S$ & $U-T S+P V$ & $U+P V$ & \\
\hline Symbol & $S$ or $\varphi$ & $U$ or $E$ & $F$ & $G$ & $H$ or $I$ & $W$ \\
\hline
\end{tabular}

In the above formulæ, $P$ and $V$ should be interpreted as representing a generallsed force and generalised co-ordinate respectively.

\section{Future Work of the Commission}

Consideration was given to the policy which should govern the future activities of the Commission and its relationship to those other international bodies which deal, among other matters, with the definitions and nomenclature of their subjects.
The International Union of Pure and Applied Physics decided that the S.U.N. Commission might usefully continue to work :

(1) By co-operating with existing international bodies in the preparation of glossaries or lists of definitions with the view of making them more useful to physicists in general.

(2) By preparing, for general adoption, lists of terms occurring in two or more branches of physics.

(3) By assisting those who, in any country, are engaged in preparing such lists, with the view of bringing workers in different countries into contact and securing harmony in the results of their work.

Copies of the complete report of the Commission will be obtainable from the Physical Society (1 Lowther Gardens, London, S.W.7) at a price of $2 s .9 d$. in paper covers and $5 s$. bound in cloth.

E. G.

\title{
The Eider Duck (Somateria mollissima mollissima)
}

\section{By SeTon Gordon}

$\mathrm{T}$ HE eider duck, because of the handsome and striking plumage of the drake, is a familiar object off the coasts of Britain. It is more numerous in Scottish than in English waters, but is plentiful throughout the year off the coast of Northumbria, where the eider is known as St. Cuthbert's duck, because of the tradition in the district that St. Cuthbert, who had his cell on one of the Farne Islands, tamed the eiders of old.

In Scotland the eider duck is found both east and west, and is particularly numerous during the winter months on the sheltered sea lochs on the east side of the Isle of Skye. On the open waters of the Minch it is not really plentiful, nor is it often seen in winter on the open Atlantic west of the Hebrides. When the eider is seen at close quarters the striking beauty of both drake and duck is apparent. The drake with his black head, pale sea-green cheeks, and white breast with its faint rosy flush, is a striking object as he courts his more sober-coloured mate, but she, too, is beautiful, for a warm rosy flush is upon the rich brown feathers of her breast and back, and to relieve the monotony of her colouring there are two white bars on her wings.

The late Viscount Grey of Fallodon had an eider drake in his bird sanctuary at Fallodon for twenty-one years, and up to the last the old eider, although he was blind in one eye, delighted in courting the mallard ducks on the pond, and their rightful mates, aware that the old fellow's intentions were harmless, watched him with amused tolerance.

In very early spring, sometimes even in winter, the eider drake can be seen courting the duck that has attracted his fancy. Swimming round her, he raises himself on the water and utters soft cooing notes. It is indeed possible that the eider remains paired throughout the year, and the late Viscount Grey told me that on seeing a large flock of eiders off the coast of Northumberland one winter day he carefully counted the sexes in the flock, and found that ducks and drakes were present in exactly equal numbers.

It is a characteristic of drakes which have an 'eclipse' plumage that they take no part in the rearing of the brood, and the British eider drake is never seen near the nest. In this characteristic he is different from the eider of Spitsbergen, which nests in colonies. I visited some of these Spitsbergen colonies in the summer of 1921, and found the drakes on the island with the ducks, and in some instances standing guard while the ducks brooded their eggs. The drakes may have kept off the Arctic skuas which were present at most of these colonies of eiders, ready to swoop down and suck the eggs of any unprotected nest. Sometimes when an eider duck left her nest, after having covered it carefully with the down which lined it, she apparently thought that her eggs would be safe from the marauding skua gulls, but the skua 
on flying up, with a few swift and deft movements of the bill, exposed the eggs and made a rapid meal of them.

Sealing sloops make the journey each summer from northern Norway to Spitsbergen to gather eggs and down of the eider duck. The down is used for quilts, and the eggs are sold in the northern towns and villages of Norway, where the domestic hen (perhaps because of the difficulty of feeding it through the long Arctic winter) is rarely seen.

The eider duck is an assiduous diver, and most of its food is taken from the floor of the ocean. It is particularly fond of mussels, and the fishermen of the north-east coast have tamed eider ducks in a remarkable manner by feeding them on the mussel bait that is wasted when a sudden change of weather with rough seas, occurring after the mussels have been shelled, prevents the lines being baited with them. The eider duck feeds also upon limpets, periwinkles and razor-shells, and has been known to swallow razor-shells up to ten inches long. Small crabs, sea-urchins and star-fish are also eaten. Eider ducks are expert divers, but they do not like a rough sea, and are not happy in turbulent breaking waves where scoter and scaup are often seen swimming and diving. Eiders, both ducks and drakes, often land on some low skerry on a falling tide, and stand contentedly, dozing or preening their feathers, but the eider duck very rarely ventures above high tide-mark except during the nesting season.

I do not remember having seen an eider drake at any distance from the tide except on one occasion. This was early on a May morning, in the Isle of Skye. I was motoring along the main road between Portree and Kyleakin, and where the road skirts Loch Ainort and winds along the hill-face at a height of perhaps one hundred feet above the sea, I saw on the road what at a distance I thought was a seagull. But as I approached I saw that this was no gull, but an eider drake, and as the car neared him he flew out over the heather-covered hillside and then out over the sea. He may have been accompanying his duck in a search for a suitable nesting place, but if the duck was in the neighbourhood she did not appear, nor did she fly away with the drake.

The eider lays four to six large unspotted eggs of a greenish colour, and when she is suddenly disturbed from them she fouls her nest as she flies off, presumably to render the eggs less attractive for an animal which might otherwise make a meal off them. The ducklings take to the sea on the day they are hatched, and are able to swim and dive actively. They are excellent divers even from their earliest youth, and are able to survive and even to enjoy breaking waves, diving through them and keeping pace with the mother without diffculty. But a prolonged period of rough and cold weather soon after they are hatched is fatal to the weaker members of the broods, and a mother eider duck may often be seen with only a single duckling following her. The young ducklings have many enemies, and perhaps the most ferocious is the greater black-backed gull, which pounces down upon an unattended duckling and swallows it whole.

\section{Obituary}

\section{Prof. Christian Hülsen}

$\mathrm{W}$ $\mathrm{E}$ regret to record the death of Prof. Christian Hülsen, the archæologist, which took place at Florence on January 19 at the age of seventy-six years.

Christian Hülsen was born at Charlottenburg and was educated at the University of Berlin, where he came under the influence of Theodor Mommsen, the Roman historian. From 1882 until 1885 he studied in Italy as a travelling scholar of the Archæologieal Institute. He returned to Berlin as a schoolmaster, but in 1887 he became a secretary of the German Archæological Institute in Rome, where he remained until his retirement in 1909 . He then took up his residence in Florence and devoted the remainder of his life to writing and research.

Hülsen's main life-work as an archæologist lay in the two departments of epigraphy and topography. As an authority on the Rome of the classical, medieval and Renaissance periods he was without a rival, with the exception of the late Prof. Lanciani. His book on the Forum and its excavation by the Com. Boni achieved a wide popularity, while for more serious students his account of the excavations on that site and on the Palatine, published in 1928, is a standard of reference. Of an even more authoritative character is his "Formæ Urbis Romæ antiquæ", which is especially of value to the student for its plans of the ancient city, and its index and bibliography of the monuments. In the study of medieval and Renaissance Rome, his outstanding contributions were the publication of the Barberini codex of Giuliano de Sangallo and of the Berlin drawings of Marten van Heemskerch, the latter in collaboration with Hermann Egger. His "The Churches of Rome in the Middle Ages" is a mine of valuable detailed information.

In epigraphy Hülsen's immense fund of knowledge of Roman topography served him well in compiling the inscriptions of the city of Rome for the "Corpus Inscriptionum Latinarum". In addition to his other work which appeared in book-form, he was the author of a large number of contributions to archæological periodical publications in both Italian and German. 